\title{
Bioremoval of diethylketone by the synergistic combination of microorganisms and clays: uptake, removal and kinetic studies
}

\author{
Cristina Quintelas • Filomena Costa • \\ Teresa Tavares
}

Received: 4 April 2012 /Accepted: 22 June 2012 / Published online: 1 July 2012

(C) Springer-Verlag 2012

\begin{abstract}
The performance of two bacteria, Arthrobacter viscosus and Streptococcus equisimilis, and the effect of the interaction of these bacteria with four different clays on the retention of diethylketone were investigated in batch experiments. The uptake, the removal percentages and the kinetics of the processes were determined. S. equisimilis, by itself, had the best performance in terms of removal percentage, for all the initial diethylketone concentrations tested: 200, 350 and $700 \mathrm{mg} / \mathrm{L}$. The uptake values are similar for both bacteria. A possible mechanism to explain the removal of diethylketone includes its degradation by bacteria, followed by the adsorption of the intermediates/sub-products by the functional groups present on the cells' surfaces. The assays performed with bacteria and clays indicated that the uptake values are similar despite of the clay used, for the same microorganism and mass of clay, but in general, higher values are reached when $S$. equisimilis is used, compared to A. viscosus. Kinetic data were described by pseudo-first- and pseudo-second-order models.
\end{abstract}

Keywords Bacteria $\cdot$ Bentonite $\cdot$ Diethylketone $\cdot$ Kaolin . Sepiolite $\cdot$ Vermiculite

\section{Introduction}

Advances in science and technology produced enormous progresses in many areas of industrial development, but also

Responsible editor: Robert Duran

C. Quintelas $(\bowtie) \cdot$ F. Costa $\cdot$ T. Tavares

IBB - Institute for Biotechnology and Bioengineering,

Centre of Biological Engineering, University of Minho,

Campus de Gualtar,

4710-057 Braga, Portugal

e-mail: cquintelas@deb.uminho.pt contributed to environmental degradation due to industrial effluents. Ketones are important trace constituents of the Earth's troposphere, and like other volatile organic compounds (VOCs), they are emitted into the atmosphere from anthropogenic and biogenic sources (Aranda et al. 2004). Ketones are used as raw materials or intermediates and constitute waste products in the manufacturing of pharmaceutical, plastics, paints and lubricants. The widespread usage of these substances has resulted in their accumulation in aquatic and terrestrial environments (Hernandez et al. 2002).

The typical treatment processes used for the elimination of VOC such as oxidation, with or without flame, thermal degradation (Gasnot et al. 2000), biofiltration (Chou and Li 2010), adsorption on granular activated carbon, GAC (Buburuzan et al. 2010) and air-stripping (Kungsanant et al. 2008) are in general very expensive. Therefore, the application of microorganisms to remove/degrade ketones is used as a cost-effective alternative.

Previous works have demonstrated that bacteria successfully bind metals and some hazardous compounds (Quintelas et al. 2006; Quintelas et al. 2008; Quintelas et al. 2009a; Quintelas et al. 2010; Cai et al. 2011). These authors studied the removal of phenol, chlorophenol, $o$ cresol, hexavalent chromium and triethylamine. In previous studies, the behaviour of Arthrobacter viscosus was tested to remove diethylketone and it was found that this bacterium is able to remove $100 \%$ of the solvent, for the range of initial diethylketone concentrations of 0.8-3.9 g/L (Costa et al. 2012).

The use of natural adsorbents such as clays has attracted much attention, due to their competitive price, their large surface area and high cation exchange capacity. Two of these works are highlighted, where clays have been used for the removal of organic compounds with success: Zhang et al. (2010) reported the sorption and desorption of 
carbamazepine from water by smectite clays and $\mathrm{Li}$ et al. (2010) adsorbed tetracycline on kaolinite clay.

Clay materials can also be modified using a variety of chemical/physical treatments to achieve the desired surface properties for better immobilisation of contaminants (Sarkar et al. 2010) or can be combined with microorganisms, aiming an efficient removal of hazardous compounds. The interaction between microorganism and clays for the removal of hazardous compounds was tested by several authors: Froehner et al. (2009a) enhanced the biodegradation of naphthalene and anthracene by modified vermiculite mixed with soil, Ohnuki et al. (2009) studied the reduction of $\mathrm{Pu}$ (VI) to a less harmful $\mathrm{Pu}(\mathrm{IV})$ by a mixture of Bacillus subtilis and kaolinite clay and Chen et al. (2009) determined the ability of living and nonliving Pseudomonas putida CZ1 cells, clays (goethite, kaolinite, smectite and manganite) and their composites to accumulate copper and zinc from a liquid medium and elucidated the role of microbes in the mobility of heavy metals. Quintelas et al. (2009b) evaluated the removal of $\mathrm{Cd}(\mathrm{II}), \mathrm{Cr}(\mathrm{VI}), \mathrm{Fe}$ (III) and $\mathrm{Ni}(\mathrm{II})$ from aqueous solutions by an Escherichia coli biofilm on kaolin.

The modelling of the equilibrium data is essential for industrial applications of a biosorption process because it allows the comparison between different biomaterials under different operational conditions. On the other hand, the knowledge on the adsorption rate is important for designing batch treatment systems. This work aims the development of a technology that combines properties of bacteria and clays as removers of hazardous compounds, applicable to the treatment of aqueous solutions contaminated with solvents. Batch assays were performed to investigate the biosorption behaviour of A. viscosus and Streptococcus equisimilis and of four different clays mixed with those bacteria in the treatment of diethylketone aqueous solutions. The effect of the initial concentration of the xenobiotic on the performance of the bacteria and the effect of the mass of clay on the performance of clays mixed with bacteria were studied. The kinetic data were analysed by pseudo-first- and pseudo-second-order models. The comparison between the behaviour of both bacteria and bacteria mixed with four different clays was made.

\section{Materials and methods}

\section{Materials}

The bacteria used were $S$. equisimilis (CECT 926) and $A$. viscosus (CECT 908) from the Spanish Type Culture Collection-University of Valencia. Aqueous diethylketone (3-pentanone) solutions were prepared by diluting diethylketone (Acros Organics) in distilled water. The kaolin was obtained from Minas de Barqueiros, S.A. (Apúlia, Portugal) (average particle diameter of $2.37 \mu \mathrm{m}$, Brunauer-Emmett-
Teller (BET) surface area of $13.7 \mathrm{~m}^{2} / \mathrm{g}$ and porosity of $45.5 \%$ ), sepiolite was obtained from Tolsa, S.A. (Spain) (average particle diameter of $0.58 \mathrm{~mm}$, BET surface area of $108 \mathrm{~m}^{2} / \mathrm{g}$ and porosity of $49 \%$ ), bentonite clay was collected in Alentejo (Portugal) (average particle diameter of $0.2 \mathrm{~mm}$, BET surface area of $11.9 \mathrm{~m}^{2} / \mathrm{g}$ and porosity of $11 \%$ ) and vermiculite was obtained from Sigma-Aldrich (average particle diameter of $0.45 \mathrm{~mm}$, BET surface area of $39 \mathrm{~m}^{2} / \mathrm{g}$ and porosity of $10 \%$ ).

Methods

\section{Batch biosorption-uptake and removal percentage}

The retention of the diethylketone by the four different clays mixed with bacteria was evaluated through batch experiments at the appropriated temperature, 26 and $37^{\circ} \mathrm{C}$, respectively, for A. viscosus and $S$. equisimilis. The experiments were performed with $250-\mathrm{mL}$ Erlenmeyer flasks containing $150 \mathrm{~mL}$ of the ketone solution with circa $1,000 \mathrm{mg} / \mathrm{L}$ and different amounts of clay $(0.1,0.25,0.5,0.75,1$ and $1.5 \mathrm{~g})$ and $15 \mathrm{~mL}$ of microorganism solution (growth culture circa $0.3 \mathrm{~g} / \mathrm{L}$ ). All clays were sterilized before used. The flasks were rotated constantly at $150 \mathrm{rpm}$ until equilibrium was reached. Previous assays were made to determine the time needed for equilibrium to be reached (15 days). Samples of $1 \mathrm{~mL}$ were taken after reaching equilibrium, centrifuged at $2,500 \times \mathrm{g}$ for $10 \mathrm{~min}$ and the supernatant liquid was analysed for the ketone using gas chromatography (GC) (Chrompack CP 9001) equipped with a flame ionization detector (FID). Assays using only the microorganisms were also performed in this study (21 days of assay). The concentrations of diethylketone used in these runs were 200,350 and $700 \mathrm{mg} / \mathrm{L}$.

All the experimental work was done in duplicate. The results presented are an average of both assays. The relative standard deviation and relative error of the experimental measurements were less than 2 and $5 \%$, respectively.

\section{Batch biosorption—kinetics}

The experimental procedure was similar to 'Batch biosorption —uptake and removal percentage', but now several samples of $0.3 \mathrm{~mL}$ were collected from the duplicated flasks at different time intervals. The samples were analysed using GC.

\section{Characterization procedures}

The GC employed herein was a Chrompack CP 9001, equipped with an FID, and separations were performed using a TRB-Wax capillary column $(30 \mathrm{~m} \times 0.32 \mathrm{~mm}$ i.d. $\times 0.25 \mu \mathrm{m})$. The operating conditions were as follows: the column was held initially at $50{ }^{\circ} \mathrm{C}$, then heated at $10^{\circ} \mathrm{C} / \mathrm{min}$ to $100{ }^{\circ} \mathrm{C}$, held at $100{ }^{\circ} \mathrm{C}$ for $4 \mathrm{~min}$, then heated again at $40{ }^{\circ} \mathrm{C} / \mathrm{min}$ to $200{ }^{\circ} \mathrm{C}$ and finally held at $200{ }^{\circ} \mathrm{C}$ 
for $2 \mathrm{~min}$. The temperatures of injector and detector were maintained at $250{ }^{\circ} \mathrm{C}$. Nitrogen was used as a carrier gas at a flow rate of $30 \mathrm{~mL} / \mathrm{min}$ and the injections were made in the split mode with a split ratio of 1:14. Under these conditions, the retention time for ketone was $2.2 \mathrm{~min}$.

\section{Results and discussion}

Biotreatment of solvent aqueous solutions

\section{Uptake and removal percentage-microorganisms}

The experimental assays were performed using microorganisms, A. viscosus and S. equisimilis, at initial solvent concentrations of 200,350 and $700 \mathrm{mg} / \mathrm{L}$. The removal of diethylketone by both microorganisms showed similar profiles with a steady decrease in $C / C_{0}$ with time, for all the initial concentrations used (Fig. 1). After $550 \mathrm{~h}$, almost all diethylketone is removed by $A$. viscosus while the removal by $S$. equisimilis appears to be faster. The uptake and removal percentages are presented in Tables 1 and 2 , and these batch adsorption data showed slight differences on the biosorption performance between the two microorganisms. As expected, the uptake increased with the increase of the initial diethylketone concentration. The removal percentage also increased, and this is an unexpected result because, in general, high concentrations reduce the average distance between the adsorbing species, affecting the charge distribution of their neighbours and altering the ability of the species to migrate to the biomass surface, resulting in reduced adsorption. However, this unexpected increase of removal percentage observed could be explained by the increase on the biomass concentration, confirmed by the increase on the turbidity, probably motivated by the presence of a carbon source (diethylketone).

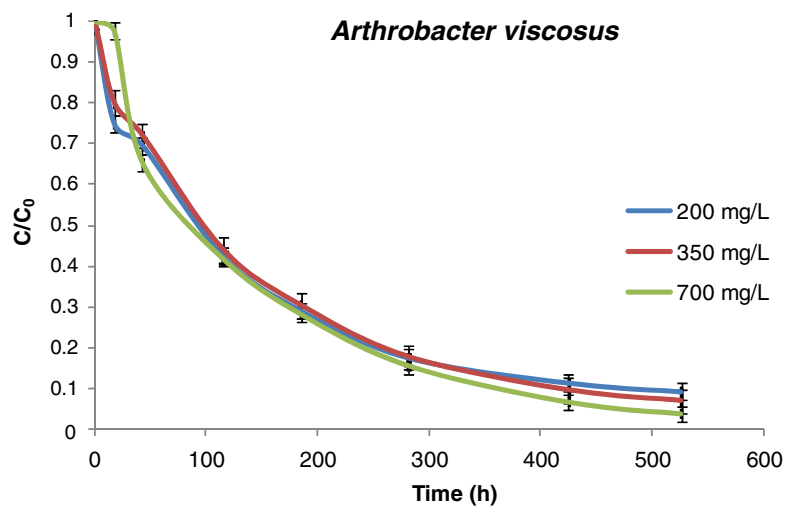

Different approaches could be used to define the mechanism of biotreatment. The microorganisms can degrade diethylketone to less harmful products and/or can adsorb the diethylketone through fixation by the functional groups present on the cells' surfaces.

The main elements responsible for the biodegradation of compounds are enzymes. Arthrobacter species produces enzymes as $\beta-1,3$-glucanase, $\alpha$-mannanase, chitinase, amylase (Werner et al. 1993), NADH oxidase, catalase, succinic dehydrogenase, fumarase, aconitase (Meganathan and Ensign 1976) and monooxygenases (Kim et al. 2008), and Streptococcus species produces enzymes as serine proteinase, $N$-acetylglucosaminidase, cysteine proteinase, NAD-glycohydrolase, ADPribosyltransferase and arginine deiminase (Collin and Olsén 2003). Different authors suggested pathways for the degradation of ketones: Eubanks et al. (1974) studied the degradation of methyl ethyl ketone by Nocardia sp. originating from acetaldehyde and affirm that this reaction is catalysed by enzymes, as oxidases and dehydrogenases are also present in Arthrobacter and Streptococcus species. Park et al. (2009) reported the degradation of ketones catalysed by monooxygenases to form esters.

In the present experimental work, some non-identified intermediates were found during the experiment with the formation of chromatographic peaks not belonging to the tested compound, but at the end of the assay, these intermediates also disappear. These results suggested that the degradation occurs in parallel with adsorption performed by the functional groups present on the cells' surfaces.

The carbonyl group present on the ketones structure is polar as a consequence of the higher electronegativity of the oxygen centre compared to the one of carbonyl carbon and, for that reason, ketones are nucleophilic in the oxygen and electrophilic in the carbon. As the carbonyl group interacts with water by hydrogen bonding, ketones are hydrogen bond acceptors usually originating compounds with hydroxyl groups.

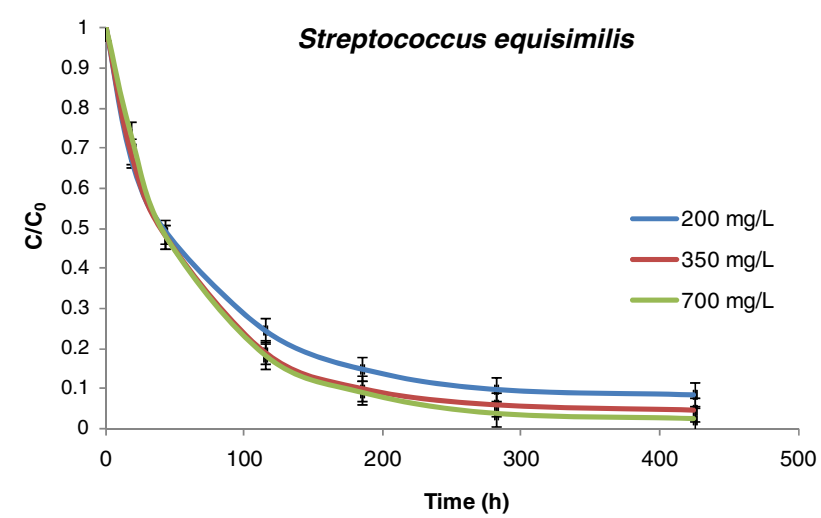

Fig. 1 Ratio between residual and initial solvent concentration $\left(C / C_{0}\right)$ versus time (in hours) for different initial diethylketone concentrations, for both microorganisms 
Table 1 Solvent uptake (in milligrams per gram) and removal percentage, obtained with $A$. viscosus $\left(26^{\circ} \mathrm{C}, 150 \mathrm{rpm}, C_{0}=200,350 \mathrm{and} 700 \mathrm{mg} / \mathrm{L}\right)$ and $A$. viscosus mixed with different masses of clay $\left(26^{\circ} \mathrm{C}, 150 \mathrm{rpm}, C_{0}=1,000 \mathrm{mg} / \mathrm{L}\right)$

\begin{tabular}{|c|c|c|c|c|c|c|c|c|c|c|c|}
\hline \multicolumn{3}{|c|}{ Arthrobacter viscosus } & \multirow[b]{2}{*}{$\begin{array}{l}\text { Mass } \\
(\mathrm{g})\end{array}$} & \multicolumn{2}{|c|}{$\begin{array}{l}\text { Bentonite }+ \\
\text { A. viscosus }\end{array}$} & \multicolumn{2}{|c|}{$\begin{array}{l}\text { Kaolin }+ \\
\text { A. viscosus }\end{array}$} & \multicolumn{2}{|c|}{$\begin{array}{l}\text { Sepiolite }+ \\
\text { A. viscosus }\end{array}$} & \multicolumn{2}{|c|}{$\begin{array}{l}\text { Vermiculite }+ \\
\text { A. viscosus }\end{array}$} \\
\hline $\begin{array}{l}C_{\mathrm{I}} \\
(\mathrm{mg} / \mathrm{L})\end{array}$ & $\begin{array}{l}\text { Uptake } \\
(\mathrm{mg} / \mathrm{g})\end{array}$ & $\mathrm{Rp}(\%)$ & & $\begin{array}{l}\text { Uptake } \\
\text { (mg/g) }\end{array}$ & $\mathrm{Rp}(\%)$ & $\begin{array}{l}\text { Uptake } \\
\text { (mg/g) }\end{array}$ & $\operatorname{Rp}(\%)$ & $\begin{array}{l}\text { Uptake } \\
\text { (mg/g) }\end{array}$ & $\mathrm{Rp}(\%)$ & $\begin{array}{l}\text { Uptake } \\
(\mathrm{mg} / \mathrm{g})\end{array}$ & $\mathrm{Rp}(\%)$ \\
\hline 200 & 0.17 & 90.6 & 0.10 & 1.35 & 98.2 & 1.35 & 98.3 & 1.34 & 97.8 & 1.35 & 98.3 \\
\hline 350 & 0.32 & 93.0 & 0.25 & 0.54 & 98.3 & 0.54 & 98.2 & 0.54 & 97.9 & 0.54 & 98.2 \\
\hline \multirow[t]{4}{*}{700} & 0.67 & 96.1 & 0.50 & 0.27 & 98.3 & 0.27 & 98.3 & 0.27 & 98.0 & 0.27 & 98.1 \\
\hline & & & 0.75 & 0.18 & 98.0 & 0.18 & 98.3 & 0.18 & 98.0 & 0.18 & 98.2 \\
\hline & & & 1.00 & 0.14 & 98.3 & 0.14 & 98.1 & 0.14 & 98.3 & 0.14 & 98.3 \\
\hline & & & 1.50 & 0.09 & 98.2 & 0.09 & 97.8 & 0.09 & 98.0 & 0.09 & 98.3 \\
\hline
\end{tabular}

Previous studies developed by Lameiras et al. (2008) indicated that the main functional groups of $A$. viscosus biomass include bonded hydroxyl groups and $-\mathrm{NH}, \mathrm{C}-\mathrm{N}$ stretching and $\mathrm{N}-\mathrm{H}$ deformations, $\mathrm{COO}^{-}$anions, $-\mathrm{SO}_{3}$ and $-\mathrm{CH}$ groups. On the other hand, according to van der Mei et al. (1996), the main functional groups present on Streptoccoccus sp. are amide I and amide II, with absorption bands at 1,653 and $1,541 \mathrm{~cm}^{-1}$ respectively, phosphate bands at $1,237 \mathrm{~cm}^{-1}$ and sugar bands at $1,070 \mathrm{~cm}^{-1}$ next to hydrocarbon absorption bands in the wavelength region between 3,000 and $2,800 \mathrm{~cm}^{-1}$. Some of these groups are responsible for the adsorption of diethylketone or its intermediates and contribute to the biotreatment. As it could be seen in Tables 1 and 2, the removal of diethylketone ranges from 90.6 to $97.7 \%$, and the best performances were obtained for the S. equisimilis.

\section{Uptake and removal percentage-microorganisms mixed with clays}

Experimental assays were performed using microorganisms, A. viscosus and $S$. equisimilis mixed with clays, for a solution of initial organic compound concentration of circa $1,000 \mathrm{mg} / \mathrm{L}$ and masses of clay between 0.1 and $1.5 \mathrm{~g}$. The ratio between residual and initial diethylketone concentration $\left(C / C_{0}\right)$ as a function of contact time is presented in Fig. 2 and shows a similar profile for all the assays. As it was observed in previous studies using clays for the removal of diethylketone (Quintelas et al. 2011), the removal of this solvent by the clays mixed with bacteria presents a typical adsorption kinetics, which includes two phases: the initial and very fast phase mainly constituted by a surface phenomenon and a second phase that depends mostly on the cellular metabolism.

Batch adsorption data showed slight differences on the adsorption performance between the four clays mixed with the bacteria (Table 1 and 2). The clays used on this study are bentonite, sepiolite, vermiculite and kaolin. The first three clays consist of tetrahedral-octahedral-tetrahedral sheets (2:1 layer) and kaolin differs from the others as it has a 1:1 layer (1:1 dioctahedral phyllosilicate).

It is observable in Tables 1 and 2 that as the mass of clay increases, the solvent uptake, defined as the mass of solvent over the mass of adsorbent, decreases and this is true for all the clays tested, for the diethylketone concentration of $1,000 \mathrm{mg} / \mathrm{L}$. The values of uptake are equal for all the clays (for the same mass of clay and the same microorganism used) but present higher values when $S$. equisimilis is used.

Table 2 Solvent uptake (in milligrams per gram) and removal percentage, obtained with S. equisimilis $\left(37^{\circ} \mathrm{C}, 150 \mathrm{rpm}, C_{0}=200,350 \mathrm{and} 700 \mathrm{mg} /\right.$ $\mathrm{L})$ and $S$. equisimilis mixed with different masses of clay $\left(37^{\circ} \mathrm{C}, 150 \mathrm{rpm}, C_{0}=1,000 \mathrm{mg} / \mathrm{L}\right)$

\begin{tabular}{|c|c|c|c|c|c|c|c|c|c|c|c|}
\hline \multicolumn{3}{|c|}{ Streptococcus equisimilis } & \multirow[b]{2}{*}{$\begin{array}{l}\text { Mass } \\
(\mathrm{g})\end{array}$} & \multicolumn{2}{|c|}{$\begin{array}{l}\text { Bentonite }+ \\
\text { S. equisimilis }\end{array}$} & \multicolumn{2}{|c|}{$\begin{array}{l}\text { Kaolin }+ \\
\text { S. equisimilis }\end{array}$} & \multicolumn{2}{|c|}{$\begin{array}{l}\text { Sepiolite }+ \\
\text { S. equisimilis }\end{array}$} & \multicolumn{2}{|c|}{$\begin{array}{l}\text { Vermiculite }+ \\
\text { S. equisimilis }\end{array}$} \\
\hline $\begin{array}{l}C_{\mathrm{I}} \\
(\mathrm{mg} / \mathrm{L})\end{array}$ & $\begin{array}{l}\text { Uptake } \\
(\mathrm{mg} / \mathrm{g})\end{array}$ & $\mathrm{Rp}(\%)$ & & $\begin{array}{l}\text { Uptake } \\
(\mathrm{mg} / \mathrm{g})\end{array}$ & $\operatorname{Rp}(\%)$ & $\begin{array}{l}\text { Uptake } \\
(\mathrm{mg} / \mathrm{g})\end{array}$ & $\operatorname{Rp}(\%)$ & $\begin{array}{l}\text { Uptake } \\
(\mathrm{mg} / \mathrm{g})\end{array}$ & $\operatorname{Rp}(\%)$ & $\begin{array}{l}\text { Uptake } \\
(\mathrm{mg} / \mathrm{g})\end{array}$ & $\operatorname{Rp}(\%)$ \\
\hline 200 & 0.17 & 91.4 & 0.10 & 1.66 & 98.6 & 1.67 & 98.6 & 1.67 & 98.6 & 1.67 & 98.6 \\
\hline 350 & 0.33 & 95.4 & 0.25 & 0.67 & 98.5 & 0.67 & 98.6 & 0.67 & 98.6 & 0.67 & 98.6 \\
\hline \multirow[t]{4}{*}{700} & 0.68 & 97.7 & 0.50 & 0.33 & 98.6 & 0.33 & 98.6 & 0.33 & 98.6 & 0.33 & 98.5 \\
\hline & & & 0.75 & 0.22 & 98.6 & 0.22 & 98.6 & 0.22 & 98.6 & 0.22 & 98.6 \\
\hline & & & 1.00 & 0.17 & 98.6 & 0.17 & 98.6 & 0.17 & 98.6 & 0.17 & 98.6 \\
\hline & & & 1.50 & 0.11 & 98.6 & 0.11 & 98.5 & 0.11 & 98.6 & 0.11 & 98.6 \\
\hline
\end{tabular}


$0.1 \mathrm{~g}$ clay+S. equisimilis

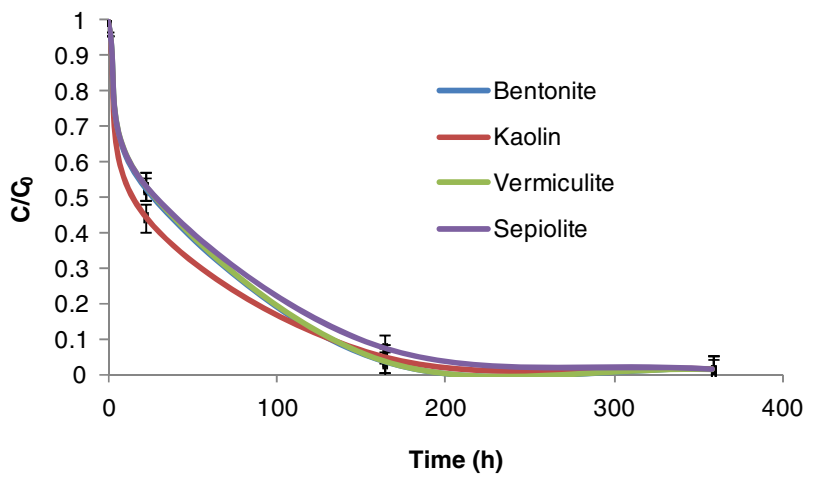

$0.1 \mathrm{~g}$ clay $+A$. viscosus

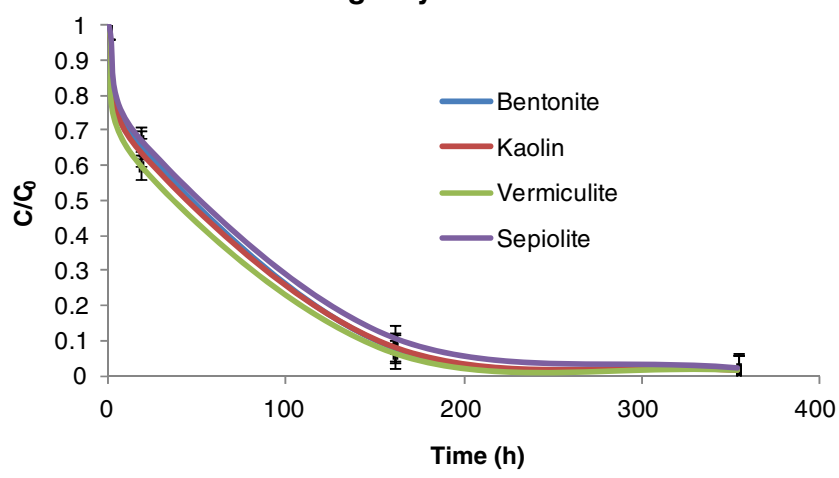

$1.5 \mathrm{~g}$ clay+S. equisimilis

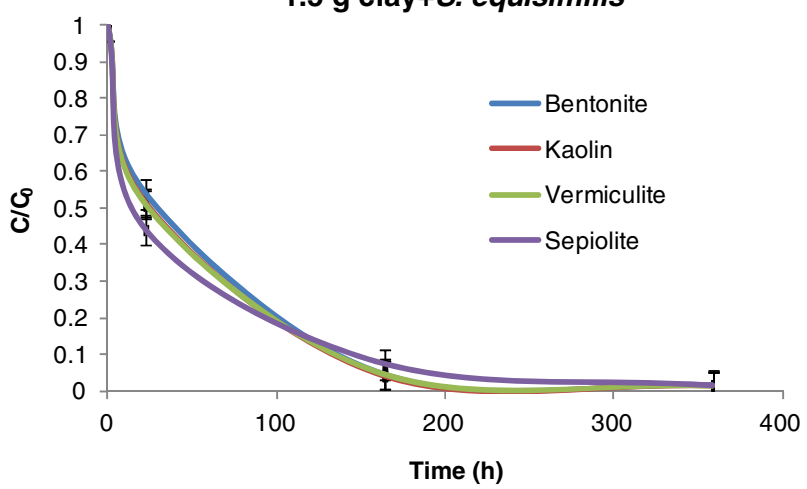

$1.5 \mathrm{~g} \mathrm{clay}+A$. Viscosus

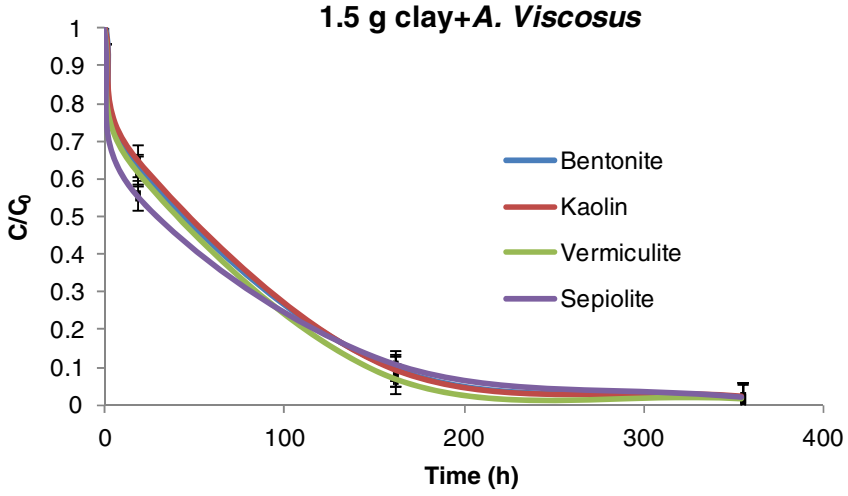

Fig. 2 Ratio between residual and initial solvent concentration $\left(C / C_{0}\right)$ as a function of contact time, for adsorbent doses of 0.1 and $1.5 \mathrm{~g}$

Almost complete removal of diethylketone was achieved for all clays mixed with bacteria, with removal percentages approximating $99 \%$. Removal data increase with the ketone initial concentration, as can be observed in Tables 1 and 2 .

Chen et al. (2009) also discover that the use of clays combined with $P$. putida increase the removal of cooper and zinc. These authors affirm that microorganisms are often intimately intermixed with mineral phases, as clays, to form complex, highly hydrated, high surface area composite materials through attractive van der Waals interactions, hydrogen bonding or ion bridging. Moreover, the surface properties of these composite materials can differ dramatically from those of pure bacterial to those of mineral surfaces, particularly in terms of surface charge, double-layer properties, number of reactive sites and potential metalbinding affinity.

The use of fungi combined with clays was also studied by Morley and Gadd (1995). These authors reported that mixtures of montmorillonite and fungal biomass showed reduced uptake of metals, depressed below calculated values by up to $37 \%$ at $\mathrm{pH} 4$, possibly due to masking of exchange sites. Mixtures of kaolinite and fungi showed no reduction in metal uptake as the values obtained were similar to those obtained with the individual components. Bacteria, due to their small size, could avoid the masking of exchange sites.
There are many functional groups on the $A$. viscosus and S. equisimilis cell walls, as described in 'Uptake and removal percentage-microorganisms mixed with clays' and on clays that can coordinate with diethylketone. Previous results (Quintelas et al. 2011) showed that the main changes on functional groups present on clay surfaces that might be responsible for the adsorption process are the $-\mathrm{OH}$ stretching, $\mathrm{SiO}$ stretching and $\mathrm{OH}$ deformations, for all the clays used. A possible mechanism to explain the removal of diethylketone is similar to the one presented before: bacteria degrade the diethylketone to simpler products and these are adsorbed by the functional groups present on the bacterial cell walls or on the clays' surface.

\section{Kinetic approach}

According to Froehner et al. (2009b), various steps may control the kinetics of the adsorption phenomena on clays such as mass transfer of solute from solution to the boundary film, mass transfer of solute through the boundary film, internal diffusion of solute and sorption of solute onto sites. Some of them are fast, such as sorption onto sites and others are slow, depending on some parameters like agitation and surface homogeneity. 
Table 3 Pseudo-first-order and pseudo-second-order kinetic models describing the adsorption of solvent onto the bacteria at different initial diethylketone concentrations

\begin{tabular}{|c|c|c|c|c|c|c|c|}
\hline \multirow[t]{2}{*}{$C_{0}(\mathrm{mg} / \mathrm{L})$} & \multirow[t]{2}{*}{$q_{\mathrm{e}} \exp (\mathrm{mg} / \mathrm{g})$} & \multicolumn{3}{|c|}{ Pseudo-first-order } & \multicolumn{3}{|c|}{ Pseudo-second-order } \\
\hline & & $q_{\mathrm{e}} \mathrm{cal}(\mathrm{mg} / \mathrm{g})$ & $k_{1}(\mathrm{~h})$ & $R^{2}$ & $q_{\mathrm{e}} \mathrm{cal}(\mathrm{mg} / \mathrm{g})$ & $k_{2}(\mathrm{~g} \mathrm{mg} \mathrm{h})$ & $R^{2}$ \\
\hline \multicolumn{8}{|l|}{ A. viscosus } \\
\hline 200 & 0.17 & 0.16 & 0.0036 & 0.997 & 0.20 & 0.0593 & 0.993 \\
\hline 350 & 0.32 & 0.32 & 0.0035 & 0.994 & 0.39 & 0.0240 & 0.994 \\
\hline 700 & 0.67 & 0.69 & 0.0035 & 0.994 & 0.81 & 0.0113 & 0.999 \\
\hline \multicolumn{8}{|c|}{ S. equisimilis } \\
\hline 200 & 0.17 & 0.16 & 0.0069 & 0.991 & 0.19 & 0.1401 & 0.999 \\
\hline 350 & 0.33 & 0.25 & 0.0053 & 0.984 & 0.36 & 0.0708 & 0.999 \\
\hline 700 & 0.68 & 0.65 & 0.0065 & 0.998 & 0.77 & 0.0220 & 0.997 \\
\hline
\end{tabular}

Several models can be used to describe the overall mechanism. The kinetic experiments were performed using only microorganisms for initial diethylketone concentrations of
200, 350 and $700 \mathrm{mg} / \mathrm{L}$ and using microorganisms mixed with different masses of clays, between 0.1 and $1.5 \mathrm{~g}$, for an initial diethylketone concentration of $1,000 \mathrm{mg} / \mathrm{L}$. The

Table 4 Comparison between the pseudo-first-order and the pseudo-second-order kinetic models for the adsorption of solvent onto the clays mixed with bacteria at various masses of adsorbent $(1,000 \mathrm{mg} / \mathrm{L}$ of solvent)

\begin{tabular}{|c|c|c|c|c|c|c|c|c|c|c|c|c|}
\hline \multirow{2}{*}{$\begin{array}{l}\text { Mass } \\
(\mathrm{g})\end{array}$} & \multicolumn{3}{|c|}{ Pseudo-first-order } & \multicolumn{3}{|c|}{ Pseudo-second-order } & \multicolumn{3}{|c|}{ Pseudo-first-order } & \multicolumn{3}{|c|}{ Pseudo-second-order } \\
\hline & $\begin{array}{l}q_{\mathrm{e}} \text { cal } \\
(\mathrm{mg} / \mathrm{g}) \\
\text { Bentonit }\end{array}$ & $\begin{array}{l}k_{1}(\mathrm{~h}) \\
\text { A. viscos }\end{array}$ & $R^{2}$ & $\begin{array}{l}q_{\mathrm{e}} \mathrm{cal} \\
(\mathrm{mg} / \mathrm{g})\end{array}$ & $\begin{array}{l}k_{2}(\mathrm{~g} / \\
\mathrm{mg} \mathrm{h})\end{array}$ & $R^{2}$ & $\begin{array}{l}q_{\mathrm{e}} \mathrm{cal} \\
(\mathrm{mg} / \mathrm{g}) \\
\text { Kaolin }\end{array}$ & $\begin{array}{l}k_{1}(\mathrm{~h}) \\
\text { viscosus }\end{array}$ & $R^{2}$ & $\begin{array}{l}q_{\mathrm{e}} \mathrm{cal} \\
(\mathrm{mg} / \mathrm{g})\end{array}$ & $\begin{array}{l}k_{2}(\mathrm{~g} / \\
\mathrm{mg} / \mathrm{h})\end{array}$ & $R^{2}$ \\
\hline 0.10 & 1.51 & 0.0091 & 0.991 & 1.41 & 0.0399 & 0.992 & 1.25 & 0.0071 & 0.997 & 1.41 & 0.0425 & 0.993 \\
\hline 0.25 & 0.50 & 0.0067 & 0.996 & 0.56 & 0.1017 & 0.993 & 0.55 & 0.0091 & 0.998 & 0.56 & 0.1147 & 0.994 \\
\hline 0.50 & 0.24 & 0.0063 & 0.990 & 0.28 & 0.2362 & 0.995 & 0.27 & 0.0164 & 1.000 & 0.28 & 0.4309 & 0.998 \\
\hline 0.75 & 0.16 & 0.0072 & 0.999 & 0.19 & 0.3197 & 0.993 & 0.16 & 0.0083 & 0.996 & 0.19 & 0.4294 & 0.996 \\
\hline 1.00 & 0.11 & 0.0040 & 0.965 & 0.14 & 0.4969 & 0.995 & 0.12 & 0.0087 & 0.996 & 0.14 & 0.5188 & 0.996 \\
\hline 1.50 & 0.10 & 0.0090 & 0.984 & 0.09 & 0.6527 & 0.994 & 0.08 & 0.0066 & 0.999 & 0.09 & 0.6134 & 0.993 \\
\hline & \multicolumn{6}{|c|}{ Sepiolite $+A$. viscosus } & \multicolumn{6}{|c|}{ Vermiculite $+A$. viscosus } \\
\hline 0.10 & 1.26 & 0.0065 & 0.997 & 1.41 & 0.0360 & 0.991 & 1.23 & 0.0079 & 0.997 & 1.40 & 0.0520 & 0.995 \\
\hline 0.25 & 0.49 & 0.0068 & 0.995 & 0.55 & 0.1359 & 0.996 & 0.58 & 0.0090 & 0.992 & 0.56 & 0.1146 & 0.994 \\
\hline 0.50 & 0.26 & 0.0071 & 0.998 & 0.28 & 0.2282 & 0.994 & 0.26 & 0.0083 & 0.999 & 0.28 & 0.2260 & 0.994 \\
\hline 0.75 & 0.17 & 0.0074 & 0.998 & 0.19 & 0.3649 & 0.995 & 0.20 & 0.0090 & 0.987 & 0.19 & 0.3150 & 0.993 \\
\hline 1.00 & 0.10 & 0.0040 & 0.937 & 0.14 & 0.5505 & 0.996 & 0.11 & 0.0041 & 0.937 & 0.14 & 0.4208 & 0.993 \\
\hline \multirow[t]{2}{*}{1.50} & 0.09 & 0.0068 & 0.991 & 0.09 & 0.8238 & 0.996 & 0.08 & 0.0077 & 0.997 & 0.09 & 0.7068 & 0.994 \\
\hline & \multicolumn{6}{|c|}{ Bentonite $+S$. equisimilis } & \multicolumn{6}{|c|}{ Kaolin $+S$. equisimilis } \\
\hline 0.10 & 1.57 & 0.0105 & 0.999 & 1.72 & 0.0498 & 0.996 & 1.20 & 0.0069 & 0.986 & 1.70 & 0.0650 & 0.998 \\
\hline 0.25 & 0.46 & 0.0061 & 0.950 & 0.69 & 0.1172 & 0.996 & 0.45 & 0.0062 & 0.950 & 0.69 & 0.1313 & 0.997 \\
\hline 0.50 & 0.33 & 0.0123 & 1.000 & 0.34 & 0.2481 & 0.996 & 0.31 & 0.0126 & 0.999 & 0.34 & 0.3334 & 0.998 \\
\hline 0.75 & 0.22 & 0.0118 & 0.999 & 0.23 & 0.3583 & 0.996 & 0.19 & 0.0113 & 0.996 & 0.23 & 0.5347 & 0.998 \\
\hline 1.00 & 0.11 & 0.0047 & 0.886 & 0.17 & 0.4858 & 0.996 & 0.10 & 0.0046 & 0.863 & 0.17 & 0.5988 & 0.997 \\
\hline \multirow[t]{2}{*}{1.50} & 0.10 & 0.0102 & 0.999 & 0.11 & 0.6882 & 0.995 & 0.10 & 0.0103 & 0.999 & 0.11 & 0.7657 & 0.996 \\
\hline & \multicolumn{6}{|c|}{ Sepiolite + S. equisimilis } & \multicolumn{6}{|c|}{ Vermiculite $+S$. equisimilis } \\
\hline 0.10 & 1.45 & 0.0069 & 0.998 & 1.72 & 0.0431 & 0.996 & 1.21 & 0.0070 & 0.971 & 1.72 & 0.0480 & 0.996 \\
\hline 0.25 & 0.55 & 0.0060 & 0.995 & 0.68 & 0.1153 & 0.996 & 0.46 & 0.0062 & 0.943 & 0.69 & 0.1150 & 0.995 \\
\hline 0.50 & 0.28 & 0.0076 & 0.987 & 0.34 & 0.2566 & 0.997 & 0.30 & 0.0097 & 0.997 & 0.34 & 0.2589 & 0.997 \\
\hline 0.75 & 0.18 & 0.0071 & 0.979 & 0.23 & 0.4016 & 0.997 & 0.20 & 0.0094 & 0.998 & 0.23 & 0.3641 & 0.996 \\
\hline 1.00 & 0.11 & 0.0045 & 0.938 & 0.17 & 0.6293 & 0.998 & 0.11 & 0.0046 & 0.918 & 0.17 & 0.5466 & 0.997 \\
\hline 1.50 & 0.09 & 0.0074 & 0.976 & 0.11 & 0.8955 & 0.998 & 0.10 & 0.0098 & 0.998 & 0.11 & 0.7672 & 0.997 \\
\hline
\end{tabular}


experimental kinetic data were fitted by pseudo-first- and pseudo-second-order models. The linearized forms of the pseudo-first-order model and pseudo-second-order model (Quintelas et al. 2011) are shown below as Eqs. (1) and (2), respectively:

$\log \left(q_{\mathrm{e}}-q_{\mathrm{t}}\right)=\log \left(q_{\mathrm{e}}\right)-k_{1} \cdot t$

$t / q_{\mathrm{t}}=1 /\left(k_{2} \cdot q_{\mathrm{e}}^{2}\right)+t / q_{\mathrm{e}}$

where $q_{\mathrm{e}}$ is the amount of solvent sorbed at equilibrium per mass unity of sorbent (in milligrams per gram), $q_{\mathrm{t}}$ is the amount of diethylketone sorbed at time $t$ per mass unity of sorbent (in milligrams per gram), $k_{1}$ the pseudo-firstorder rate constant (in hour) and $k_{2}$ is the pseudosecond-order rate constant (in grams per milligrams per hour). The rate constants, predicted uptakes and corresponding correlation coefficients are summarized in Table 3 for the assays using only microorganisms and in Table 4 for the assays using bacteria mixed with clays. The plots of both, first- and second-order models, are shown in Figs. 3 (only for microorganisms), 4 (as an example, for $A$. viscosus and $S$. equisimilis with vermiculite pseudo-first-order model) and 5 (as an example, for A. viscosus and S. equisimilis with bentonite pseudo-second-order model).

For all studied systems, straight lines with high correlation coefficients $(0.984-0.999$, for assays with bacteria, and $0.863-1$, for assays with bacteria mixed with clays) were obtained. The pseudo-first-order model assumes that the reaction rate is limited only by one step of sorption on a single class of sites and that all sites are time dependent (Fonseca et al. 2009). Pseudosecond-order kinetics model assumes that the ratelimiting step of the process may be chemisorption (Kumar et al. 2011), involving valence forces through the sharing or exchange of electrons between the biomass/biomass mixed with clays and diethylketone, complexation, coordination and/or chelation (Suazo-Madrid et al. 2011).
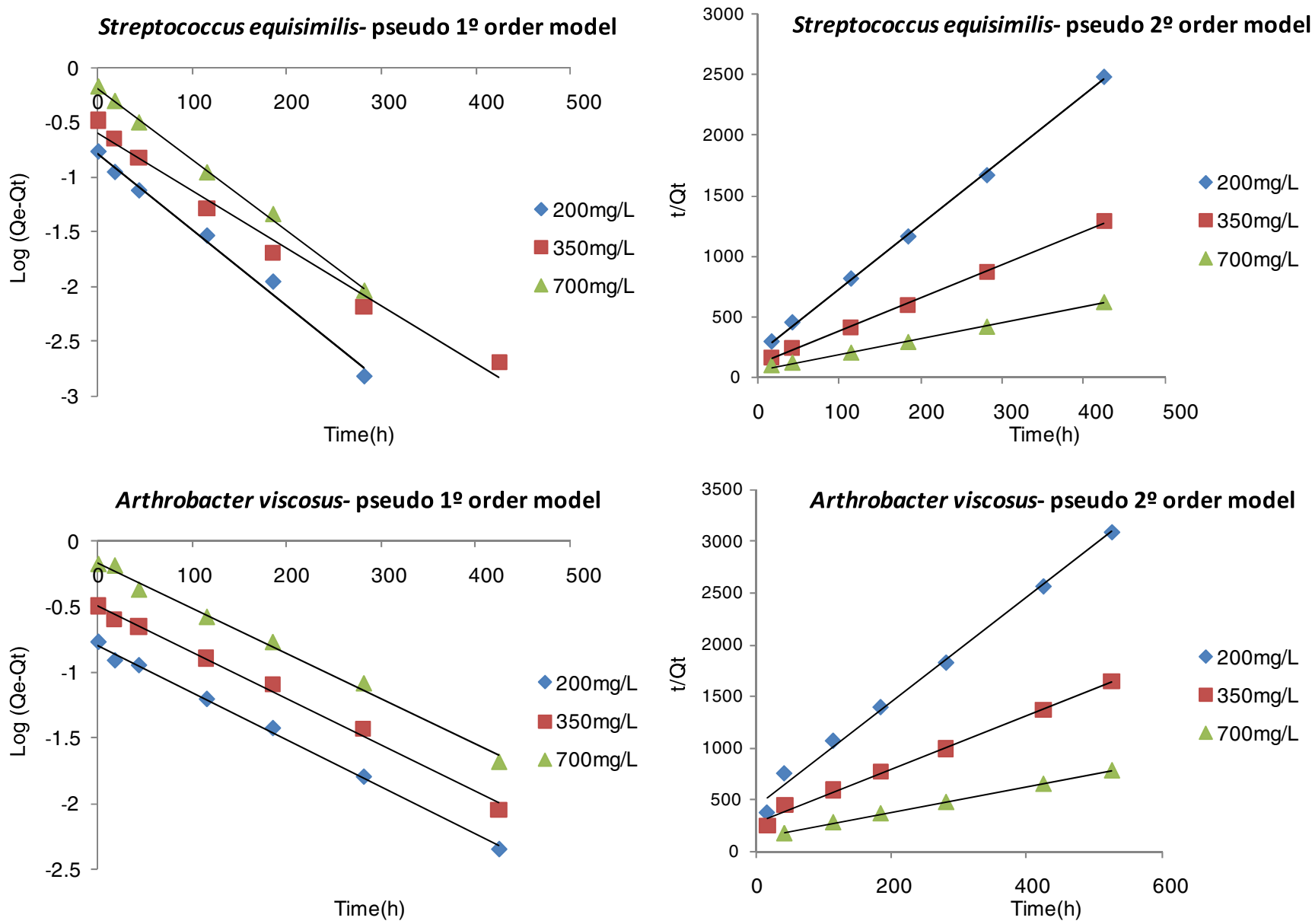

Fig. 3 Pseudo-first-order and pseudo-second-order kinetics for the adsorption of solvent onto A. viscosus and S. equisimilis for initial solvent concentrations of 200,350 and $700 \mathrm{mg} / \mathrm{L}$ 
Arthrobacter viscosus + Vermiculite- pseudo $1^{\circ}$ order model

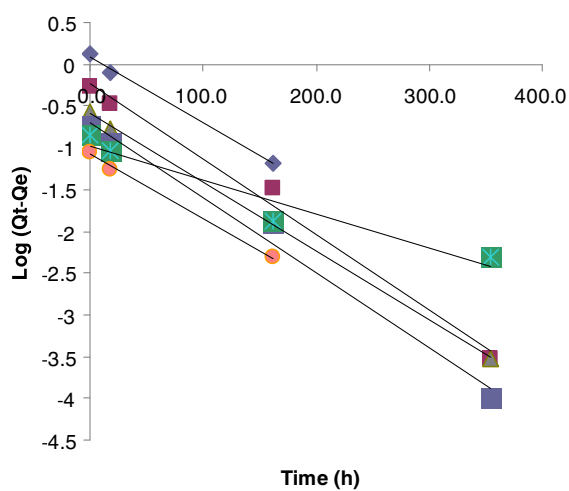

Streptococcus equisimilis + Vermiculite- pseudo $1^{\circ}$ order model

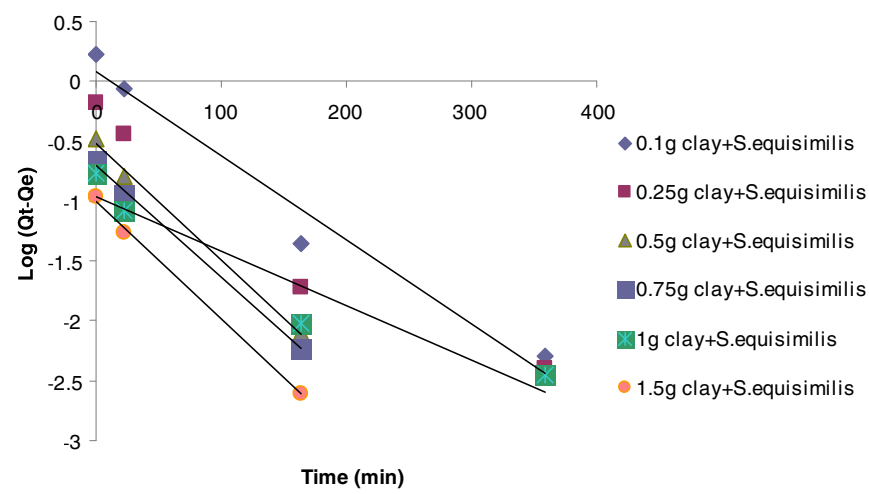

Fig. 4 Pseudo-first-order kinetics for the adsorption of solvent onto bentonite mixed with bacteria for an initial concentration of solvent of circa $1,000 \mathrm{mg} / \mathrm{L}$ (in $150 \mathrm{~mL}$ ) and adsorbent doses between $0.1 \mathrm{~g}$ and $1.5 \mathrm{~g}$

It may be concluded from Table 3 that the predicted equilibrium capacity values are in agreement with the experimental ones for $A$. viscosus using pseudo-first order-model. When using S. equisimilis, the experimental data are well-fitted by the pseudo-first-order model, for the initial solvent concentration of $700 \mathrm{mg} / \mathrm{L}$, and by the pseudo-second-order kinetics, for the initial solvent concentration of $350 \mathrm{mg} / \mathrm{L}$. For the lower concentration used, $200 \mathrm{mg} / \mathrm{L}$, the calculated $q_{\mathrm{e}}$ values agree with the experimental data for both models.

In Table 4, the correlation coefficients were always higher than 0.99 , for the pseudo-second-order model. In the case of the pseudo-first-order model, the correlation coefficients ranged between 0.86 and 0.99 , suggesting the insufficiency of the model to fit the kinetic data for the conditions of the assay.

Ofomaja (2010) and Wu et al. (2009) studied the relationship between pseudo-second-order parameters and biosorption performance. These authors established a relationship, described as the approaching equilibrium factor $\left(R_{\mathrm{w}}\right)$, between the pseudo-second-order model constants and

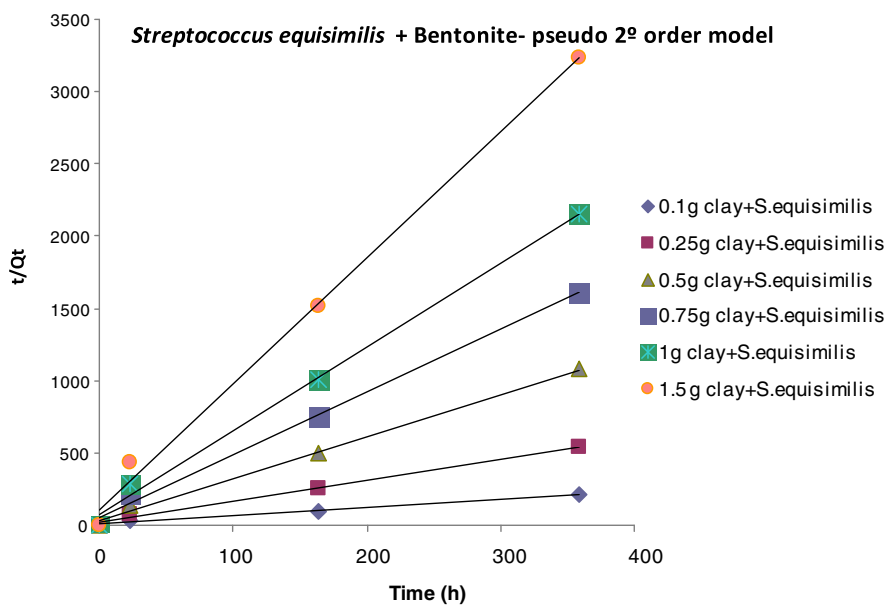

the characteristic kinetic curve. This approaching equilibrium factor $\left(R_{\mathrm{w}}\right)$ is defined as:

$R_{\mathrm{w}}=1 /\left(1+k_{2} \cdot q_{\mathrm{e}} \cdot t_{\mathrm{ref}}\right)$

where $t_{\text {ref }}$ is the longest operation time (based on kinetic experiments), $q_{\mathrm{e}}$ is the uptake value calculated from Eq. (2) and $k_{2}$ is the pseudo-second-order constant.

Wu et al. (2009) refer to four different situations depending on the $R_{\mathrm{w}}$ value:

1. $R_{\mathrm{w}}=1$, type of kinetic curve: linear, not approaching equilibrium

2. $1>R_{\mathrm{w}}>0.1$, type of kinetic curve: slightly curved, approaching equilibrium

3. $0.1>R_{\mathrm{w}}>0.01$, type of kinetic curve: largely curved, well approaching equilibrium

4. $R_{\mathrm{w}}<0.01$, type of kinetic curve: pseudo-rectangular, drastically approaching equilibrium

When $R_{\mathrm{w}}=1$, as in the first situation, biosorption is ineffective as equilibrium cannot be reached.

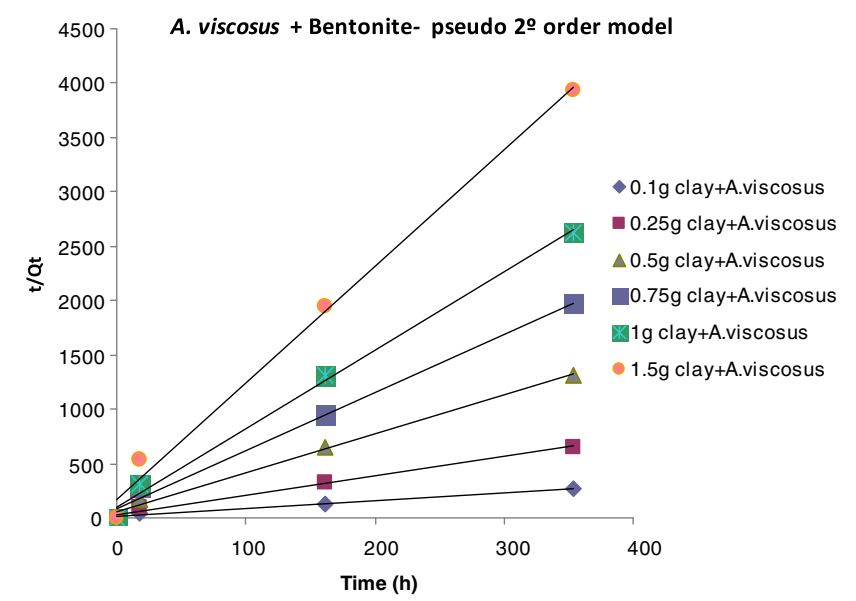

Fig. 5 Pseudo-second-order kinetics for the adsorption of solvent onto bentonite clay mixed with bacteria for an initial concentration of solvent of circa $1,000 \mathrm{mg} / \mathrm{L}$ (in $150 \mathrm{~mL}$ ) and adsorbent doses between $0.1 \mathrm{~g}$ and $1.5 \mathrm{~g}$ 
In this study, the values for $R_{\mathrm{w}}$ were found to range between 0.023 and 0.053 , for $A$. viscosus mixed with clays, and between 0.022 and 0.036 , for $S$. equisimilis mixed with clays, for the biotreatment of aqueous solutions with an initial concentration of $1,000 \mathrm{mg} / \mathrm{L}$ of diethylketone. These values are situated between 0.1 and 0.01 , which means that the kinetic curve is largely curved with a good approach to equilibrium confirming the good performance of the system used.

\section{Conclusions}

It was demonstrated that $A$. viscosus and $S$. equisimilis, by themselves or interacting with bentonite, sepiolite, kaolinite and vermiculite clays, are able to remove efficiently diethylketone from aqueous solutions. Almost complete removal of diethylketone was achieved when using the bacteria mixed with clays, with removal percentages of approximately 98-99\%. A possible mechanism to explain these observations is that diethylketone is degraded by the bacteria and then the intermediates/sub-products may be adsorbed by the functional groups present on the cell wall and/or clay surfaces. The kinetics were well described by the pseudo-second-order model and an approaching equilibrium factor $\left(R_{\mathrm{w}}\right)$ was used to establish a relationship between pseudo-second-order parameters and biotreatment.

Acknowledgments The authors would like to gratefully acknowledge the financial support of this project by the Fundação para a Ciência e Tecnologia, Ministério da Ciência e Tecnologia, Portugal and co-funding by FSE (programme QREN-POPH). Cristina Quintelas thanks FCT for a post-doc grant. The authors would like also to thank Minas de Barqueiros, S.A., Prof. Rui Boaventura (FEUPPortugal) and Prof. Isabel Correia Neves (Dep Química, UM, Portugal) who gently offered the clays.

\section{References}

Aranda A, de Mera YD, Rodríguez A, Morales L, Martínez E (2004) Kinetic study of the gas-phase reactions of $\mathrm{Cl}$ radicals with 3pentanone and 3-hexanone. J Phys Chem A 108:7027-7031

Buburuzan AM, Macoveanu M, Cojocaru C, Catrinescu C (2010) Experimental design to optimise the removal efficiency of $o$ xylene from gaseous flux by adsorption. J Environ Prot Ecol $11: 623-634$

Cai T, Chen L, Ren Q, Cai S, Zhang J (2011) The biodegradation pathway of triethylamine and its biodegradation by immobilized Arthrobacter protophormiae cells. J Hazard Mater 186:59-66

Chen X, Hu S, Shen C, Dou C, Shi J, Chen Y (2009) Interaction of Pseudomonas putida CZ1 with clays and ability of the composite to immobilize copper and zinc from solution. Bioresour Technol 100:330-337

Chou M-S, Li S-C (2010) Elimination of methyl ethyl ketone in air streams by a biofilter packed with fern chips. Environ Eng Sci 27:679-687
Collin M, Olsén A (2003) Extracellular enzymes with immunomodulating activities: variations on a theme in Streptococcus pyogenes. Infect Immun 71:2983-2992

Costa F, Quintelas C, Tavares T (2012) Kinetics of biodegradation of diethylketone by Arthrobacter viscosus. Biodegradation 23:81-92

Eubanks EF, Forney FW, Larson AD (1974) Purification and characterization of the nocardial acetylesterase involved in 2-butanone degradation. J Bacteriol 120:1133-1143

Fonseca B, Maio H, Quintelas C, Teixeira A, Tavares T (2009) Retention of $\mathrm{Cr}(\mathrm{VI})$ and $\mathrm{Pb}(\mathrm{II})$ on a loamy sand soil: kinetics, equilibria and breakthrough. Chem Eng J 152:212-219

Froehner S, Cardoso da Luz E, Maceno M (2009a) Enhanced biodegradation of naphthalene and anthracene by modified vermiculite mixed with soil. Water Air Soil Pollut 202:169-177

Froehner S, Martins RF, Furukawa W, Errera MR (2009b) Water remediation by adsorption of phenol onto hydrophobic modified clay. Water Air Soil Pollut 199:107-113

Gasnot L, Decottignies V, Turbieza A, Pauwels JF (2000) Experimental and kinetic analysis of the thermal degradation of the methylethylketone in methane/air flames UMR CNRS 8522. Combust Sci Technol 161:1-25

Hernandez R, Zappi M, Colucci J, Jones R (2002) Comparing the performance of various advanced oxidation processes for treatment of acetone contaminated water. J Hazard Mater 92:33-50

Kim Y-M, Jung S-H, Chung Y-H, Yu C-B, Rhee I-K (2008) Cloning and characterization of a cyclohexanone monooxygenase gene from Arthrobacter sp. L661. Biotechnol Bioproc Eng 13:40-47

Kumar PS, Ramalingam S, Sathishkumar K (2011) Removal of methylene blue dye from aqueous solution by activated carbon prepared from cashew nut shell as a new low-cost adsorbent. Korean J Chem Eng 28:149-155

Kungsanant S, Kitiyanan B, Rirksomboon T, Osuwan S, Scamehorn JF (2008) Toluene removal from nonionic surfactant coacervate phase solutions by vacuum stripping. Sep Purif Technol 63:370 378

Lameiras S, Quintelas C, Tavares MT (2008) Biosorption of Cr(VI) using a bacterial biofilm supported on granular activated carbon and on zeolite. Bioresour Technol 99:801-806

Li Z, Schulz L, Ackley C, Fenske N (2010) Adsorption of tetracycline on kaolinite with $\mathrm{pH}$-dependent surface charges. J Colloid Interface Sci 351:254-260

Meganathan R, Ensign JC (1976) Stability of enzymes in starving Arthrobacter crystallopoietes. J Gen Microbiol 94:90-96

Morley GF, Gadd GM (1995) Sorption of toxic metals by fungi and clay minerals. Mycol Res 99:1429-1438

Ofomaja AE (2010) Biosorption studies of $\mathrm{Cu}(\mathrm{II})$ onto Mansonia sawdust: process design to minimize biosorbent dose and contact time. React Funct Polym 70:879-889

Ohnuki T, Yoshida T, Ozaki T, Kozai N, Sakamoto F, Nankawa T, Suzuki Y, Francis AJ (2009) Modeling of the interaction of Pu (VI) with the mixture of microorganism and clay. J Nucl Sci Technol 46:55-59

Park YC, Shaffer C, Bennett GN (2009) Microbial formation of esters. Appl Microbiol Biotechnol 85:13-25

Quintelas C, Sousa E, Silva F, Neto S, Tavares T (2006) Competitive biosorption of ortho-cresol, phenol, chlorophenol and chromium (VI) from aqueous solution by a bacterial biofilm supported on granular activated carbon. Process Biochem 41:2087-2091

Quintelas C, Fernandes B, Castro J, Figueiredo H, Tavares T (2008) Biosorption of $\mathrm{Cr}(\mathrm{VI})$ by three different bacterial species supported on granular activated carbon - a comparative study. J Hazard Mater 153:799-809

Quintelas C, Fonseca B, Silva B, Figueiredo H, Tavares T (2009a) Treatment of chromium(VI) solutions in a pilot-scale bioreactor through a biofilm of Arthrobacter viscosus supported on GAC. Bioresour Technol 100:220-226 
Quintelas C, Rocha Z, Silva B, Fonseca B, Figueiredo H, Tavares T (2009b) Removal of $\mathrm{Cd}(\mathrm{II}), \mathrm{Cr}(\mathrm{VI}), \mathrm{Fe}(\mathrm{III})$ and Ni(II) from aqueous solutions by an E. coli biofilm supported on kaolin. Chem Eng J 149:319-324

Quintelas C, Silva B, Figueiredo H, Tavares T (2010) Removal of organic compounds by a biofilm supported on GAC: modelling of batch and column data. Biodegradation 21:379-392

Quintelas C, Figueiredo H, Tavares T (2011) The effect of clay treatment on remediation of diethylketone contaminated wastewater: uptake, equilibrium and kinetic studies. J Hazard Mater 186:1241-1248

Sarkar B, Xi Y, Megharaj M, Krishnamurti GSR, Rajarathnam D, Naidu R (2010) Remediation of hexavalent chromium through adsorption by bentonite based Arquad ${ }^{\circledR}$ 2HT-75 organoclays. J Hazard Mater 183:87-97
Suazo-Madrid A, Morales-Barrera L, Aranda-Garcia E, CristianiUrbina E (2011) Nickel(II) biosorption by Rhodotorula glutinis. $\mathrm{J}$ Ind Microbiol Biotechnol 38:51-64

van der Mei HC, Naumann D, Busscher HJ (1996) Grouping of Streptococcus mitis strains grown on different growth media by FT-IR. Infrared Phys Technol 37:561-564

Werner L, Latzko F, Hampel W (1993) Spraydrying of yeast-lytic enzymes from Arthrobacter sp. Biotechnol Tech 7:663-666

Wu F-C, Tseng R-L, Huang S-C, Juang R-S (2009) Characteristics of pseudo-second-order kinetic model for liquid-phase adsorption: a mini-review. J Chem Eng 151:1-9

Zhang W, Ding Y, Boyd SA, Teppen BJ, Li H (2010) Sorption and desorption of carbamazepine from water by smectite clays. Chemosphere 81:954-960 